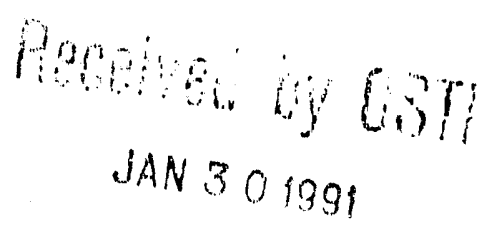

\title{
ELECTRON COLLISIONAL EXCITATION OF K- AND B-LIKE IONS
}

DOE/ER/53293--2

DE9 1006900

\author{
PROGRESS REPORT
}

Alfred Z. Msezane

Department of Physics

Atlanta, Georgia 30314

June 30, 1990

\author{
Submitted to U. S. DOE, \\ OFFICE OF FUSION ENERGY
}

\section{DISCLAIMER} This report was prepared as an account of work sponsored by an agency of the United States Goyernment. Neither the United States Government nor ansumes any legal liability or responsiemployees, makes any warranty, express or implied, of assu information, apparatus, product, or bility for the accuracy, completeness, or usefulness of any information, apparatus, product, or process disclosed, or represents that its use would not infringe price by trade name, trademark, ence herein to any spicific commercial product, process, or service by trade name, trademark, manufacturer, or otherwise does not necessarily constitute or imply its endorem. The views mendation, or favoring by the United States Government or any agency thereof. The vews and opinions of authors expressed herein do not 


\section{PROGRESS REPORT}

During the period covered by this report, $9 / 1 / 89-6 / 30 / 90$, the following were accomplished:

(1) Collision cross sections for $\mathrm{Cr} 5+$ between the ground state and the excited states $4 s{ }^{2} S, 4 p 2 p 0,4 d 2 D, 3 p^{5} 3 d^{2}\left({ }^{1} S,{ }^{1} D\right) 2 p O, 3 p^{5} 3 d^{2}\left({ }^{1} D{ }^{2} D O\right)$ and $3 p^{5} 3 d^{2}\left(1 G,{ }^{1} D\right){ }^{2} F 0$ were calculated ${ }^{1}$ using a 9-state R-matrix method ${ }^{2}$ for the energy range from near threshold to about 20Ry. The results were contrasted with those from NIEM ${ }^{3} 5 \mathrm{CC}$ and DW. 4 Significant differences amoung the $9 C C, 5 C C$ and DW results were noted for $4 s 2 S, 4 p 2 p o$ and $4 d$ $2 D$, even away from the resonance energy region, which we attributed to the importance of coupling. For the elastic and the $4 f 2 \mathrm{FO}$ cross sections, the $9 \mathrm{CC}$ and $5 \mathrm{CC}$ and the $5 \mathrm{CC}$ and $2 \mathrm{CC}$ results, respectively are in good agreement. Measurement is necessary to determine the magnitudes of the various cross sections we calculated.

(2) Using our elaborate $\mathrm{N}^{2}+$ target wave function, we pertormedli a 10state R-matrix calculation for excitation cross sections from ground state to the doublet states arising from the $2 s 2 p^{2}$ and $2 s^{2} 3 /(I=0,1$ and 2$)$ configurations and to the $2 s 2 p^{4} 4 p$ state for $1.6 \leq E \leq 15 R y$. Distorted wave cross sections were also compated and compared with the $C C$ results. For some transitions, DW results differ from the $\mathrm{CC}$ ones by as much as a factor of 2.5. We interpret the large discrepancy between DW and $\mathrm{CC}$ as a manifestation of strong coupling effects for the e- $\mathrm{N}^{2}+$ system. It is expected that the effects will even be more significant for both the atom and the singly ionized ion.

(3) Historically, we have used the NMFECC computing facilities through support from Oak Ridge National Laboratory, without which we could not carry out competitive research. Consequently, we acknowledged support for the electron excitation calculations of the core-excited $\mathrm{Na} /$ quartet states 6 and photoionization of $\mathrm{Na}$. Both calculations required extensive but different target wave functions. We have includeo copies of the submitted manuscripts / page 
proof showing the acknowledgements. Initially, large amounts of computer times are required for generation of extensive C.I. target wave functions. 


\section{REFERENCES}

1. A. Z. Msezane, W. Richards and R. J. W. Henry, Phys. Rev. A, submitted (1990).

2. K. A. Berrington, P. G. Burke, W. D. Robb, M. Le Dourneuf, K. T. Taylor and Vo Ky Lan, Comput. Phys. Cornmun 14, 367 (1978).

3. R. J. W. Henry, S. P. Rountree and E. R. Smith, Comput. Phys. Commun. 23, 233 (1981).

4. M. S. Pindzola, D. C. Griffin and C. Bottcher, Phys. Rev. A 39,2385 (1989).

5. A. Z. Msezane, K. J. Reed and R. E. H. Clark, Phys. Rev. A submitted (1990).

6. A.Z. Msezane and P. Awuah, J. Phys. B (submitted, revised) (1990). 


\section{PRESENTATIONS}

1. "Excitation Cross Sections for K-Like Cr by Electron Impact," W. Richards, J. Lee, W. Armstrong-Mensah, A. Z. Msezane and R. J. W. Henry, Abstracts, XIV ICPEAC, 362 (1989).

2. "Electron Collision Cross Sections for Boron-Like Nitrogen," A. Z. Msezane, R. E. Clark and K. J. Reed, Abstracts, XIV ICPEAC, 363 (1989).

3. "Cross Sections for Some Core-Excited Na I Quartet States" Proc. GEC 89, Program and Abstracts, Palo Alto (1989). 

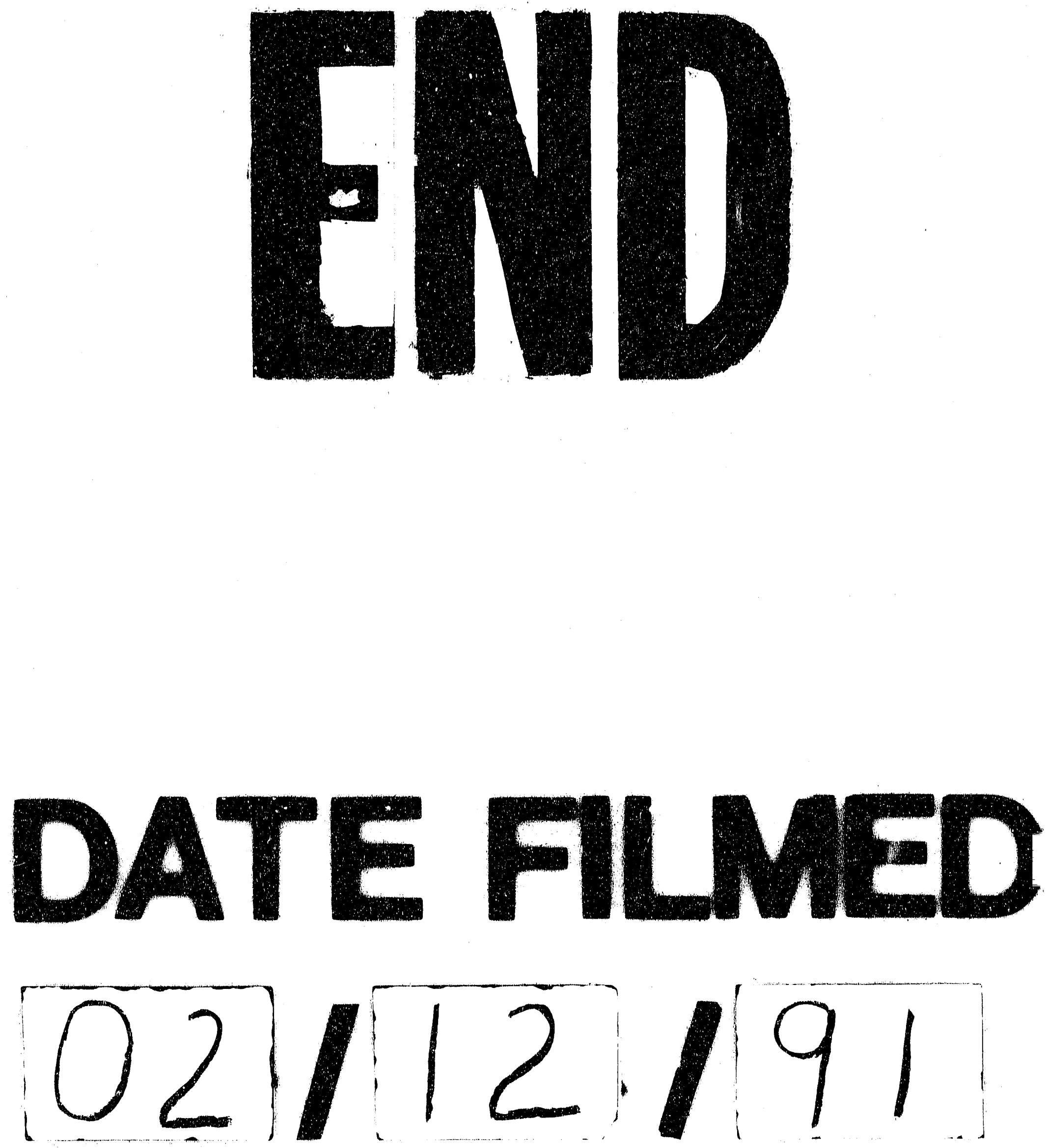
- 